\title{
A content analysis of food advertisements appearing in parenting magazines
}

\author{
Jennifer A Manganello ${ }^{1, *}$, Katherine Clegg Smith², Katie Sudakow and \\ Amber C Summers ${ }^{2}$ \\ 'Department of Health Policy, Management, and Behavior, University at Albany School of Public Health, \\ One University Place, Rensselaer, NY 12144, USA: ${ }^{2}$ Department of Health, Behavior and Society, \\ Johns Hopkins Bloomberg School of Public Health, Baltimore, MD, USA
}

Submitted 23 March 2012: Final revision received 27 September 2012: Accepted 11 October 2012: First published online 7 December 2012

\begin{abstract}
Objective: Childhood obesity is a growing problem in the USA. As parents play a major role in shaping a child's diet, the present study examines food advertisements (ads) directed towards parents in parenting and family magazines.

Design: Given the potential for magazines to influence attitudes and knowledge, we used content analysis to examine the food ads appearing in four issues each of six different parenting and family magazines from 2008 ( $n 24$ ).

Setting: USA.

Subjects: Food ads in parenting and family magazines.

Results: We identified 476 food ads, which represented approximately $32 \%$ of all ads in the magazine sample. Snack foods (13\%) were the most frequently observed food ads, followed by dairy products $(7 \%)$. The most frequently used sales theme was 'taste' (55\%). Some ads promoted foods as 'healthy' (14\%) and some made specific health claims (18\%), such as asserting the product would help lower cholesterol. In addition to taste and health and nutrition appeals, we found several themes used in ad messages to promote products, including the following: 'convenience', 'economical', 'fun' and 'helping families spend time together'. We also found that over half ( $n$ 405, 55.9\%) of products $(n$ 725) advertised were products of poor nutritional quality based on total fat, saturated fat, sodium, protein, sugar and fibre contents, and that ads for such products were slightly more likely to use certain sales themes like 'fun' $(P=0 \cdot 04)$ and 'no guilt' $(P=0 \cdot 03)$.

Conclusions: Interventions should be developed to help parents understand nutritional information seen in food ads and to learn how various foods contribute to providing a balanced family diet.
\end{abstract}

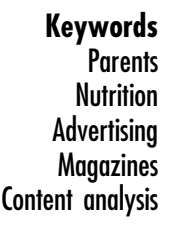

Childhood obesity is a growing problem in the USA, with the prevalence rising from $5 \%$ for ages 2 to 19 years in the early 1970 s to $17 \%$ as of $2007-2008^{(1)}$. Unhealthy diet is a significant contributor to the obesity problem ${ }^{(2)}$, and parents not only make decisions about their own diet, but also their children's diet through foods purchased, attitudes conveyed and transfer of nutritional information.

There are numerous potential contributors to parents' dietary knowledge and attitudes. Parents have been demonstrated to obtain nutritional information from professionals, magazines, newspapers, television (TV) and social networks $^{(3,4)}$. One study reported that although people trust the media less than sources such as health professionals for nutrition information, $20 \%$ of participants still trusted mass media advertising ${ }^{(4)}$. Food advertisements (ads) can influence consumers' diet ${ }^{(5)}$ and may also influence the diet of children whose parents are exposed to messages ${ }^{(6)}$. However, much of the existing research conducted on food ads has focused on ads targeted to children on $\mathrm{TV}^{(7-9)}$ and in children's magazines ${ }^{(10,11)}$.

Even though a child's diet is shaped by a parent or guardian, there is limited literature on food ads targeting adults, especially parents. International studies of magazine food ads have found that many are for products high in sugar or fat and low in fibre ${ }^{(12,13)}$, that magazines targeting poorer readers contain more ads for unhealthier foods ${ }^{(13)}$, and that ads often portray foods as nutritious and healthy even when many advertised products are not part of the food pyramid ${ }^{(14)}$ or are highly processed ${ }^{(15)}$. Moreover, food ads in women's magazines emphasize 'lifestyle success' as opposed to nutritional messages ${ }^{(16)}$ and taste is a common theme of ad messages ${ }^{(17)}$. A study of four US women's magazines between 1975 and 1990 found that appeals focused on taste, convenience and quality of foods, while mention of nutritional claims increased over time ${ }^{(18)}$; another established taste to be the most 
common sales appeal, followed by nutritional modifications, including reduced sugar ${ }^{(19)}$. Another study highlighted characteristics of foods advertised in women's magazines targeting African Americans ${ }^{(20)}$.

Although there is some related literature, we could find no studies specifically examining magazine food ads directed at parents. The goal of the present study is to examine the frequency and nature of food ads in parenting and family magazines to consider how child- and familyoriented foods are specifically marketed to parents. The research draws heavily on the theory of Mere Exposure Effect (MEE), which suggests, as per Social Cognitive Theory (SCT), that repeated exposures to a brand will encourage a consumer to purchase that brand ${ }^{(21,22)}$. Affective theories of marketing also apply ${ }^{(22)}$, given the use of emotional appeals and images aimed at parents. In addition, the Elaboration Likelihood Model (ELM) suggests that attitudes can change from traits of an ad not directly related to the product or information about the product but instead involving peripheral messages appealing to the consumer $^{(22,23)}$, such as imagery used or facial expressions of people shown in the ad (i.e. photos of happy children). SCT may also play a role if celebrities are used as product endorsers, as audiences may develop a positive attitude towards the product if they admire the person in the ad or have similar traits to that person ${ }^{(24)}$.

In addition to food ad content, we are also interested in the nutritional value of advertised products and the accuracy of the nutritional claims. We found no studies examining nutritional content of foods advertised in magazines in the USA, and specifically, none related to parenting magazines. Prior studies of TV food ads suggest that the foods advertised are not foods that would be considered part of a recommended diet ${ }^{(25)}$ and eating advertised foods would result in exceeding recommended daily values for fat, saturated fat, sodium and sugar, while consuming insufficient amounts of fibre, dairy and certain vitamins and minerals ${ }^{(8,13,26)}$

Given our interest in both ad content and nutritional value of foods advertised, our research questions are:

1. What proportion of ads in parenting magazines are for food items and what types of food products are advertised?

2. What images and messages do food ads use to sell their products?

3. What nutritional and health claims are made?

4. How do advertising claims about food items compare with actual nutrition information of the items?

\section{Methods}

\section{Sample}

Study data came from a sample of parenting and familyoriented magazines published in 2008. To identify the sample, we conducted a search on 29 April 2008 in Ulrich's International Periodicals Directory using inclusion criteria (published in the USA, written in English, circulation of 100000 or more) and the following title search terms: parent [or] child [or] pregnancy [or] family [or] baby. This search located sixty-three magazine titles. We then reviewed each title and excluded any magazine titles that were not paid, were regional as opposed to national, were religious in nature, and were published less than eight times per year. We included all six titles that remained: American Baby (2000000), Family Circle (3800 000), Family Fun (1 700 000), Parents (2 200 000), Parenting (1300 000) and Parent \& Child $(1200000)^{(27)}$. We could not find specific readership details for the magazines with the exception of Parents ${ }^{(28)}$ and Family Circle $^{(29)}$. Data suggest that readers of these two magazines are primarily women and over half come from households with an income of over \$US 50000 . Also of note is that while paid subscriptions to magazines have been on the decline, Parenting was one of only two of the top twenty-five magazines with an increase in subscriptions of greater than $2 \%$ in $2010^{(30)}$.

We constructed a sample of twenty-four issues by selecting the same four months (March, June, September and December) to cover seasonality for all six titles, an approach similar to other studies ${ }^{(18)}$. We considered a food ad as any ad selling a food or beverage product, gum, candy, and baby food or formula. When reviewing ads, we considered all ads sized $1 / 3$ page or greater, which accounts for the vast majority of advertising in the main body of the magazines (i.e. excluding 'classified' type ads at the end of the magazine). Others have used similar criteria for ad selection ${ }^{(14)}$. We excluded any ads that were advertorials, similar to Adams and White ${ }^{(13)}$, which are usually more than 1 page and written like articles. After reviewing all twenty-four magazines, our final ad sample consisted of approximately 1500 ads (non-advertorials), of which 476 were food ads meeting our inclusion criteria. Of the 476 food ads, there were 302 unique ads and 174 duplicates. Similar to other studies ${ }^{(8)}$, we analysed all ads including duplicates because duplicate ads reflect greater potential exposure (MEE theory).

\section{Coding categories}

Table 1 provides details regarding the coding categories. We recorded the product(s) names and looked at whether article content on the page next to the ad was related to the product. Building on other studies ${ }^{(15)}$, we categorized products by product type (we put those with a frequency of less than five into an 'other' category). Similar to the approach of Jones et $a l^{(15)}$, we assessed whether the ad suggested an occasion for consuming the product and the target audience. We captured whether the ad mentioned anything related to specific ingredients or characteristics (similar to the approach used by Barr ${ }^{(17)}$ ) and whether or not the ad made claims about the product being nutritious 
Table 1 Content coding

\begin{tabular}{|c|c|c|}
\hline Coding variable & \multicolumn{2}{|l|}{ Coding options } \\
\hline Ad placement (2 parts) & \multicolumn{2}{|l|}{$\begin{array}{l}\text { How many pages ad appeared on AND } \\
\text { Placement (left, right, both sides) }\end{array}$} \\
\hline Ad full page & \multicolumn{2}{|c|}{ Yes/no } \\
\hline Product & \multicolumn{2}{|c|}{ Record product name exactly as it appears in the ad } \\
\hline \multirow{14}{*}{ Product category } & Fruit & Baked goods \\
\hline & Vegetables & Snack foods \\
\hline & Cereal & Candy \\
\hline & Bread & Seafood \\
\hline & Pasta & Meat \\
\hline & Soup & Baby food \\
\hline & Dairy products & Baby formula \\
\hline & Dessert & Sauces/dressings \\
\hline & Eggs & Soda \\
\hline & Packaged individual meals & Fruit juice \\
\hline & Packaged side dishes & Other beverages \\
\hline & Packaged family meals & Other breakfast foods \\
\hline & Fast food & Seasonings/spices/salt \\
\hline & Other & Butters/spreads \\
\hline Associated with article content & Yes/no & \\
\hline \multirow[t]{2}{*}{ Occasion for eating food } & $\begin{array}{l}\text { Snack/dessert } \\
\text { Main meal }\end{array}$ & \\
\hline & Beverage & \\
\hline \multirow[t]{6}{*}{ Ad mention of food ingredients ( 12 parts) } & Real fruit/vegetables & Protein \\
\hline & Wholesome & Fibre \\
\hline & Natural & Whole grains \\
\hline & No additives, artificial flavours, preservatives & Calcium \\
\hline & $\begin{array}{l}\text { Light or low-calorie } \\
\text { Vitamins/minerals/nutrients }\end{array}$ & $\begin{array}{l}\text { Low, reduced or no sugar added/ } \\
\text { sugar free }\end{array}$ \\
\hline & & $\begin{array}{l}\text { Low fat or low cholesterol/no trans } \\
\text { fats }\end{array}$ \\
\hline Any numeric mention related to food content & Yes/no & \\
\hline Text of ad states food is healthy or nutritious & Yes/no & \\
\hline \multirow{2}{*}{ Ad claims food improves health and how } & Yes/no & \\
\hline & List of ways could improve health & \\
\hline \multirow[t]{4}{*}{ Ad targets consumption by specific age group } & Infants & \\
\hline & Children & \\
\hline & Adults only & \\
\hline & Family & \\
\hline \multirow[t]{5}{*}{ Non-health related appeals } & Taste/family will like it/delicious & Helps families spend time \\
\hline & Convenient/time saver/fast & together/take a break/relax \\
\hline & Economical & Feel good about food/no guilt \\
\hline & Brand new product/unique product & Holiday/special occasion \\
\hline & Fun/exciting & None of these \\
\hline \multirow[t]{2}{*}{ Ad provides way to get more information } & Yes/no & \\
\hline & List of possible information sources & \\
\hline Ad has photos & Yes/no & \\
\hline Ad has a photo of product & Yes/no, In package or not & \\
\hline Famous person or character in ad & Yes/no, Who & \\
\hline Photos of real people in ad & Yes/no & \\
\hline Ethnicity, age and gender of people shown & Coding chart provided & \\
\hline \multirow[t]{4}{*}{ Expression of people shown } & Positive & \\
\hline & Neutral & \\
\hline & Negative & \\
\hline & Mixed & \\
\hline \multirow{7}{*}{$\begin{array}{l}\text { Someone shown eating or holding the product } \\
\text { Activity of people shown }\end{array}$} & Yes/no & \\
\hline & Baking/cooking & Reading \\
\hline & Feeding someone else & Making crafts \\
\hline & Swimming/in water & Playing \\
\hline & Shopping & No activity (just standing, sitting, \\
\hline & $\begin{array}{l}\text { Carrying grocery/shopping bag } \\
\text { Using media }\end{array}$ & $\begin{array}{l}\text { etc./looking at the camera/being } \\
\text { held }\end{array}$ \\
\hline & Cleaning & Other activity \\
\hline
\end{tabular}


Ads containing at least one photo were coded for whether a famous person or character was featured in the ad. People appearing in photos were coded for race, age and gender. We recorded facial expressions, activities portrayed in photos and whether people were holding or consuming the advertised product(s).

\section{Intercoder reliability}

The first author developed the codebook and trained the second and third authors to analyse content; all three authors coded ads. The codebook was revised using a test sample of food ads. Intercoder reliability statistics were calculated on a sample of fifty-seven ads ( $12 \%$ of the total), twenty-three of which were coded at the end of the coding period to account for stability over time. We assessed intercoder reliability using simple agreement and Cohen's kappa to account for agreement by chance. In seven cases, $\boldsymbol{\kappa}$ was below our designated cut-off of $0 \cdot 70$, but we kept the variable in the analysis because simple agreement was $85 \%$ or higher. Three variables were excluded because the reliability statistics did not meet this criterion: who the ad targeted for consumption of the product, other theme, and number of photos in the ad. The average simple agreement of variables used in the analysis was $91 \cdot 4 \%$ (average $\kappa=0 \cdot 82$ ).

\section{Nutrition data}

For each product advertised, we searched the company website for nutrition information ( $n$ 570, $72 \%$ ). If there was no nutrition information on the website, we then referred to the livestrong.com site ( $n$ 160, 20\%), a source chosen because of its comprehensive database and because many user entries are verified by the website. Because some ads displayed multiple products, our nutritional sample size started at 795 . We excluded products where nutrition data could not be found from either of the designated online sources ( $n 65,8 \%$ ) or where the product was labelled as having no nutritional value ( $n 5$, $1 \%$; e.g. ground black pepper and vanilla extract). Seven hundred and twenty-five products (91\%) remained for nutritional analysis.

The nutritional analysis was led by the fourth author, a Registered Dietitian. We categorized each item according to degree of nutritional quality based on the Institute of Medicine's nutrition standards for foods sold outside the school meal programme and Percent Daily Values based on a $8368 \mathrm{~kJ} / \mathrm{d}(2000 \mathrm{kcal} / \mathrm{d})$ diet applied to the specified serving size ${ }^{(31,32)}$. In line with studies in the published literature $^{(11,33-35)}$, we created a 'healthiness' formula in which products were scored in relation to dietary recommendations. Our formula included only nutrients reported for $>70 \%$ of the total sample of products. Products gained one point for providing at least $10 \%$ of the Daily Value for each of fibre $(\geq 2.5 \mathrm{~g})$ and protein $(\geq 5.0 \mathrm{~g})^{(32)}$. Products were deducted one point for exceeding each recommendation for total fat $(>35 \%$ of energy from fat), saturated fat $(>10 \%$ of energy from saturated fat), sugar ( $>35 \%$ of energy from total sugar) and sodium $(>480 \mathrm{mg}$ ) based on Institute of Medicine standards ${ }^{(31)}$. Based on this formula, the possible scores for nutritional quality range from +2 to -4 . Lower scores indicate a lower nutritional quality. Products that scored above zero were categorized as 'A' foods (higher nutritional quality); products which scored below zero were labelled as ' $\mathrm{C}$ ' foods (lower nutritional quality); and products which scored zero were labelled as 'B' foods.

To compare the nutritional quality category with ad messages, we categorized each of the ads as displaying products in category A, B or C. Those ads where nutrition information for products could not be obtained or products were displayed from multiple categories were excluded from this particular analysis, leaving a sample size of 383.

\section{Analysis}

Data were analysed using the Stata statistical software package version 11 . We conducted a largely descriptive analysis and used $\chi^{2}$ tests and $t$ tests as needed for bivariate analyses.

\section{Results}

Research question 1: What proportion of ads in parenting magazines are for food items and what types of food products are advertised?

The 476 food ads identified in our sample represented approximately $32 \%$ of the 1500 magazine ads. The majority of ads (67\%) featured only one product and 14\% had two products (average $=1 \cdot 7$, maximum $=10$ ). Snack foods ( $n$ 63, 13\%) were most commonly advertised, followed by dairy products ( $n 33,7 \%$ ), baked goods, meat and fruit juice (about $6 \%$ each; Table 2). Forty-nine per cent of ads were for products that would be considered a main meal or part of a main meal. A majority of ads appeared only on one page (80\%), and most (80\%) were full-page ads. Over half $(57 \%)$ appeared on a right page, while $22 \%$ appeared on a left page and $21 \%$ appeared on multiple pages.

\section{Research question 2: What images and messages do food ads use to sell their products?}

Several types of persuasive messages unrelated to health and nutrition were used to draw attention to products (Table 3). The most popular theme was taste ( $n$ 261, $55 \%)$. Often, ads highlighted a product's newness or reformulation ( $n$ 114, 24\%). Another common theme ( $n 79,17 \%$ ) was a convenience and time saving appeal; many ads talked about how a product was fast and easy to prepare. Food products were also commonly advertised as being fun ( $n 53,11 \%$ ), a food one could feel good about ( $n 40,8 \%$ ), or that the product would help families spend time together ( $n$ 25, 5\%). Products were also sometimes marketed using holiday themes 
Table 2 Frequency of type of food advertised in food advertisements in a sample of US parenting and family magazines from 2008 ( $n$ 476)

\begin{tabular}{lccl}
\hline Food category & $n$ & $\%$ & Food examples \\
\hline Snack food & 63 & 13 & Crackers, popcorn \\
Other & 35 & 7 & Bars, nuts \\
Dairy products (non-dessert) & 33 & 7 & Milk, yoghurt, cream cheese \\
Meat & 28 & 6 & Beef (no brand), chicken nuggets, bologna \\
Baked goods/cookies & 27 & 6 & Cookies, muffins \\
Fruit juice & 26 & 6 & Juice \\
Packaged side dish & 24 & 5 & Rice, beans \\
Fast food & 23 & 5 & Products sold at fast-food restaurants \\
Breakfast food (non-cereal) & 21 & 4 & Waffles, oatmeal, pancakes \\
Other beverages & 21 & 4 & Water, coffee, chocolate drink mix \\
Sauces/dressings & 21 & 4 & Salad dressing, pasta sauce, salsa \\
Dessert & 17 & 4 & Whipped cream, ice cream \\
Packaged family meal & 16 & 3 & Frozen lasagne, frozen chicken stir fry \\
Soup & 16 & 3 & Soup, broth \\
Cereal & 15 & 3 & Cereal \\
Candy & 14 & 3 & Jellybeans, chocolate \\
Spices/seasonings & 14 & 3 & Salt, spices, marinade \\
Packaged individual meals & 13 & 3 & Packaged lunch meals, meal bowls \\
Pasta & 10 & 2 & Pasta \\
Baby formula & 8 & 2 & Baby formula \\
Baby food & 7 & 2 & Baby food, baby yoghurt \\
Eggs & 7 & 2 & Eggs \\
Fruit & 7 & 2 & Grapes, oranges, raisins \\
Seafood & 7 & 2 & Fish fillets, fish sticks \\
\hline
\end{tabular}

( $n$ 22, 5\%). On the other hand, very few products were marketed on the basis of being economical or making one's budget stretch ( $n$ 4, $1 \%$ ).

Only $4 \%$ of ads were related to article content on the page next to it, and most ads provided a source to get more information about the product ( $n$ 296, 62\%) such as a website ( $n$ 264), a website and a telephone number ( $n$ 24), or just a telephone number ( $n$ 6). Almost all ads ( $97 \%$ ) contained a photo of the product being advertised.

As in the 'Got Milk?' ads, celebrities or famous cartoon characters were sometimes used to promote food products ( $n$ 38, 8\%). Among the 207 ads (45\%) showing real people, most were depicted with positive expressions ( $n$ 155, 76\%). Many ads showed people looking into the camera or posing in some way ( $n 62,30 \%$ ) or simply eating or holding the advertised food ( $n 54,26 \%)$. Where specific activities were shown, these included playing ( $n$ 33, 16\%), baking or cooking ( $n 22,11 \%$ ), or other ( $n$ 37, 18\%) such as gardening, raising a hand in class, running or riding a bike. Regarding the people shown in ads, they were, in order of frequency, white female adults ( $n 71,34 \%)$, white female youth ( $n 60,29 \%$ ), white male youth ( $n 53,26 \%)$, white male adults ( $n 41,20 \%)$, other race female children ( $n 35,17 \%)$, other race male youth ( $n$ 21, 10\%), other race female adults ( $n$ 13, 6\%) and other race male adults ( $n 6,3 \%)$. Coders were unable to tell the gender for twenty-five (12\%) of the people shown (mainly toddlers and infants).

\section{Research question 3: What nutritional and bealth claims are made?}

The most common claims about advertised foods were that they were natural ( $n 105,22 \%$ ), contained vitamins and minerals ( $n 89,19 \%)$ and were low in fat ( $n 87,18 \%)$. A number of ads stated that the products had no additives or preservatives ( $n 51,11 \%)$ or were sugar free ( $n 45,9 \%)$. About half of ads stated the product contained protein ( $n 50$, $11 \%$ ), real fruits or vegetables ( $n 54,11 \%$ ), or whole grains ( $n$ 48, 10\%). Some ads mentioned calcium ( $n$ 40, 8\%), wholesome ( $n 32,7 \%)$, low in calories ( $n 31,7 \%)$ and fibre ( $n$ 26, 5\%). Over a third of ads ( $n$ 181, 38\%) provided numeric information about the food product, such as $98 \%$ fat free, $0 \mathrm{~g}$ of trans fats, $100 \%$ vitamin C and $25 \%$ less sodium.

Many ads talked about healthy ingredients, and about one-fifth of ads made a direct claim that the product could improve health ( $n 87,18 \%)$. The most common claim was that the food could enhance physical or mental performance ( $n 23,26 \%$ ). An example of such a claim is a cereal ad with the slogan 'Keep' em full, Keep 'em focused', making reference to a study showing that this cereal improved children's attentiveness by $18 \%$ compared with those who ate no breakfast. Other claims included brain and eye development ( $n$ 18, $21 \%$ ), weight loss ( $n 21,24 \%$ ), boost the immune system ( $n$ 14, 16\%), help bones ( $n 13$, $15 \%)$, build muscle $(n 10,11 \%)$ and lower cholesterol ( $n$ 5, 6\%). Of these eighty-seven ads, 45\% ( $n$ 39) used the word 'healthy' or 'nutritious'. In addition to these eightyseven ads, a further twenty-six used the word 'healthy' or 'nutritious' in the ad text without making any specific claim, such as ads for products like raisins, soup and fruit juice.

\section{Research question 4: How do advertising claims about food items compare with actual nutrition information of the items?}

As described, we collected nutritional data for food products advertised and details are provided in Table 4. 
Table 3 Frequency and examples of message themes used in food advertisements (ads) in a sample of US parenting and family magazines from 2008 ( $n$ 476)

\begin{tabular}{|c|c|c|c|}
\hline Theme & $n$ & $\%$ & Examples \\
\hline Taste & 261 & 55 & $\begin{array}{l}\text { 1. Blueberry Muffin flavored Frosted Mini-Wheats: a Mini-Wheat } \\
\text { character asks the viewer 'Ever wonder what yum smells like?' An } \\
\text { arrow points to the character along with the phrase 'scratch and sniff' } \\
\text { 2. Subway Fresh Fit for Kids meals: text in ad states 'It's an easy way } \\
\text { to give kids a delicious meal they'll love' }\end{array}$ \\
\hline
\end{tabular}

New and unique

114

24

Convenient and fast

79

17

Fun

53

11

Feel good about

food/no guilt

Help families spend time together

Holiday

22

5

Economical

4
1. Lunchables Jr. Snack Combinations: ad states 'Introducing New Lunchables Jr. with Ritz mini crackers, turkey, and mozzarella strips'. The word new stands out from the other words with its bright yellow colour and outlining by shapes

2. Horizon Organic Milk with DHA: ad says 'new' in several places and text in ad states 'It's a smart new idea from Horizon Organic...'

1. Chef Boyardee's Mac \& Cheese: ad refers to the product as 'Easier Mac' and states 'No powder. No water. No mess. Just real cheese, real fast'

2. Coca Cola Breakfast Break bars: text in ad reads 'give them the quick and nutritious ready-to-eat meal..'

1. CapriSun Juice pouch: a picture of an apple appears next to a picture of a pouch of apple juice, text in ad reads '... only one comes in a pouch that screams fun'

2. Tostitos Salsa con Queso: text in ad reads 'Made for good times' with the slogan 'Free the fun'

1. Stouffers Lasagna ad: text in ad reads 'Bring home something the whole family can feel good about' and in larger letters states 'Every dinner should feel this good'

2. Kraft $2 \%$ Milk Singles: text in ad reads 'New Kraft $2 \%$ milk singles you can feel $100 \%$ good about'

1. Bagel Bites: text in ad reads 'Transform snack time into quality time with Bagel Bites' and later says while waiting for them to cook you can 'pick a fun game and enjoy quality family time'

2. Nestle Drumstick ice cream cones: text in ad reads 'You and your kids have nutty schedules already. Take time out with Nestle Drumstick Simply Dipped Ice Cream Cones'

1. Betty Crocker's sugar cookie mix: ad shows a father and his daughters making sugar cookies. The text reads: 'In less than 20 min, you can bake delicious Christmas cookies with your kids. How great is that?' This message also addresses convenience and family time

2. M\&M's ad: has wording under a yellow M\&M with a duck on it that states 'Arriving in time for Easter'

1. Ragu Old World Style Traditional Sauce: ad states 'The perfect meal when your family is growing and the economy is shrinking. With Ragu and a pound of pasta, you can feed a family of four for less than four dollars'

2. Ad for various dessert ingredients from Kraft: ad states in large letters 'Deliciously homemade. Delightfully affordable'
Applying our 'healthiness' formula to the 725 products yielded scores ranging from +2 to -4 (mean -0.57 (SD 1.1)). Over half of the products ( $n$ 405, 55.9\%) were categorized as $\mathrm{C}$, the most unhealthy category, $188(25 \cdot 9 \%)$ were categorized as $\mathrm{B}$, and the remaining $132(18 \cdot 2 \%)$ as A. Category C included foods like ice cream and candy, while category B included foods such as fish sticks and waffles. Foods in category A included products like frozen chicken stir fry and canned beans.

When comparing ad messages by nutritional quality category, we found that ads with category A products, the healthiest, were most likely to mention a product was high in fibre $(P<0 \cdot 0001)$, had whole grains $(P<0 \cdot 0001)$ and could improve health in some way $(P=0 \cdot 04)$, while ads with category $\mathrm{B}$ products were more likely to mention the food was low in calories $(P=0 \cdot 004)$ and wholesome
$(P<0 \cdot 0001)$. Ads with category $\mathrm{C}$ products, the lowest nutritional quality, were most likely to mention being sugar free $(P<0 \cdot 0001)$ and having protein $(P=0 \cdot 01)$ or vitamins $(P<0 \cdot 0001)$. All ads were equally likely to mention the product was healthy or nutritious $(P=0 \cdot 06)$. Ads with products in category $\mathrm{C}$ were slightly more likely to mention fun $(P=0 \cdot 04)$, no guilt $(P=0 \cdot 03)$ and holiday $(P=0 \cdot 04)$ themes, and those with products from category $\mathrm{B}$ were slightly more likely to highlight taste $(P=0 \cdot 04)$.

\section{Discussion}

Our findings suggest that parents reading parenting and family magazines are exposed to a large number of food ads. Many of the ads are for highly processed foods, such as snack foods, cookies, packaged side dishes and 
Table 4 Mean (and standard deviation) nutrient levels of foods advertised in food advertisements in a sample of US parenting and family magazines from $2008(n 725)$

\begin{tabular}{|c|c|c|c|c|c|c|c|c|c|}
\hline \multirow[b]{2}{*}{ Nutrient } & \multirow[b]{2}{*}{$n$} & \multicolumn{2}{|c|}{ All foods } & \multicolumn{2}{|c|}{$\begin{array}{c}\text { Category A } \\
(n \text { 132) }\end{array}$} & \multicolumn{2}{|c|}{$\begin{array}{c}\text { Category B } \\
(n 188)\end{array}$} & \multicolumn{2}{|c|}{$\begin{array}{c}\text { Category C } \\
(n \text { 405) }\end{array}$} \\
\hline & & Mean & SD & Mean & SD & Mean & SD & Mean & SD \\
\hline Energy (kJ) & 725 & $545 \cdot 2$ & $334 \cdot 7$ & $655 \cdot 6$ & 238.9 & $519 \cdot 2$ & $337 \cdot 2$ & $521 \cdot 3$ & $353 \cdot 1$ \\
\hline Energy (kcal) & 725 & $130 \cdot 3$ & $80 \cdot 0$ & $156 \cdot 7$ & $57 \cdot 1$ & $124 \cdot 1$ & $80 \cdot 6$ & $124 \cdot 6$ & $84 \cdot 4$ \\
\hline Fat (\% of energy) & 600 & $38 \cdot 8$ & $38 \cdot 1$ & $31 \cdot 6$ & $34 \cdot 2$ & $35 \cdot 1$ & $30 \cdot 3$ & $43 \cdot 3$ & $42 \cdot 0$ \\
\hline Fat $(g)$ & 724 & $4 \cdot 0$ & $4 \cdot 3$ & $3 \cdot 5$ & 3.9 & $3 \cdot 5$ & $3 \cdot 4$ & $4 \cdot 4$ & $4 \cdot 8$ \\
\hline Saturated fat $(\mathrm{g})$ & 641 & $1 \cdot 4$ & $1 \cdot 8$ & 0.5 & 0.8 & $1 \cdot 1$ & $1 \cdot 2$ & 1.9 & $2 \cdot 2$ \\
\hline Trans fat $(\mathrm{g})$ & 454 & 0.01 & $0 \cdot 1$ & 0.0 & 0.0 & 0.0 & 0.0 & 0.02 & $0 \cdot 1$ \\
\hline Sodium (mg) & 723 & $248 \cdot 4$ & $248 \cdot 1$ & $243 \cdot 3$ & 253.9 & $297 \cdot 9$ & 228.5 & $227 \cdot 3$ & $252 \cdot 2$ \\
\hline Protein $(\mathrm{g})$ & 719 & $4 \cdot 2$ & $5 \cdot 4$ & $7 \cdot 1$ & 6.5 & $4 \cdot 2$ & $4 \cdot 7$ & $3 \cdot 3$ & 4.9 \\
\hline Total carbohydrate (g) & 723 & $19 \cdot 7$ & $13 \cdot 3$ & $25 \cdot 6$ & $14 \cdot 1$ & $18 \cdot 8$ & $11 \cdot 6$ & $18 \cdot 2$ & $13 \cdot 2$ \\
\hline Sugar $(g)$ & 696 & $8 \cdot 6$ & 8.9 & $5 \cdot 8$ & $4 \cdot 5$ & $4 \cdot 2$ & $4 \cdot 5$ & $11 \cdot \overline{3}$ & $10 \cdot 2$ \\
\hline Fibre $(\mathrm{g})$ & 635 & $1 \cdot 4$ & $1 \cdot 6$ & $3 \cdot 6$ & $1 \cdot 8$ & 1.5 & $1 \cdot 2$ & 0.6 & 0.8 \\
\hline Cholesterol (mg) & 655 & $11 \cdot 8$ & $30 \cdot 4$ & $9 \cdot 6$ & $21 \cdot 2$ & $6 \cdot 6$ & $13 \cdot 0$ & $15 \cdot 2$ & $38 \cdot 3$ \\
\hline
\end{tabular}

main meals, and fast food. In their classic 1986 study of general readership magazines, Wofford et al. found diet and exercise advertisements to account for $6 \%(25 / 372)$ of magazine advertisements ${ }^{(36)}$. In our study of parenting magazines a generation later, food advertisements alone account for approximately a third of all ads. This finding raises questions as to whether this difference is driven by the focal audience (parents) or the growing predominance of food as a marketable consumer product. Both of these pathways are of potential importance in the context of the continuing rise of obesity among both children and adults. Given that parenting magazines serve as a prominent information source on children's health and child-rearing, it is important to understand the potential influence these ads may have.

While many ads were for foods that were rated as being lower in nutritional quality, analysis also revealed that a proportion of the foods advertised in these publications would be considered healthy. We found that ads with products classified in all three categories of nutritional quality utilized messages that stated the product was healthy or nutritious. Consumers likely respond positively to healthy claims, and there may even be a 'halo' effect whereby consumers are less likely to seek additional nutritional information about such products ${ }^{(37)}$. It is important to note, though, that health claims may also improve knowledge among consumers in a positive way ${ }^{(37)}$.

The themes we observed purported to provide solutions to parenting challenges, with messages that these products could save time, ensure kids have fun or create opportunities for quality family bonding. This suggests a clear link between purchase and attainment of parental expectations or aspirations. These findings align with Parkin's (2006) analysis of a century of US food advertising ${ }^{(38)}$. Parkin argues that food ads demonstrate and model for women how certain products will allow them to continue to meet the expectation that they provide healthy food for their family and demonstrate their love for their children. We saw few references to economic considerations in these ads, suggesting food advertisers may not prioritize frugality over care in relation to food choices for the family. The use of 'fun' and 'no guilt' appeals to promote less healthy foods is worthy of further consideration; such appeals may serve to defray negative emotions experienced by parents faced with food choices for their children who are increasingly aware that they are operating in an obesogenic environment ${ }^{(39)}$.

While many ads provided direct information about the product, including making statements about its healthy nature or providing information about the content of the product, others utilized a more indirect route to persuasion in line with affective theories, such as images evoking emotional responses. An overwhelming majority of ads showed people with positive expressions, suggesting the products make people happy, and ads often showed children playing or families cooking or eating together. Such images are likely to engage a reader in an emotional way, while the text about the positive attributes of the product engages the reader in a logical way. This combined effect is likely to encourage use of the product in accordance with ELM.

Our results also suggest that parents could be potentially influenced by messages that reflected theoretical concepts of MEE and SCT. Of the 476 ads, we observed that 174 were exact duplicates of other ads and many more were different ads for the same product. This finding supports MEE by suggesting that advertisers find it effective to ensure repeated exposure to messages and products. SCT is also supported by our findings, since celebrities were present in $8 \%$ of the ads, and according to SCT, people typically imitate those whom they admire.

Our study is limited by the fact that we sampled seasonally within one year and we did not collect data from parent consumers to assess effects of exposure to ads. Missing nutritional data may have skewed our nutritional quality categorization of products. Many parents do not subscribe to parenting magazines and may not be 
exposed to these messages. However, these types of magazines often appear in public libraries and waiting rooms of places like a doctor's office, increasing potential for exposure. The ads appearing in the magazines are also likely to be similar to ads appearing on TV or in other places like websites.

While food marketing to children has been widely debated and efforts have been made to encourage self-regulation by the food industry in the absence of regulations or laws curtailing marketing ${ }^{(40,41)}$, it does not appear that the marketing of food to parents has been examined in great detail. Our study provides a detailed examination of food ads in one media format (parenting magazines) specifically targeting parents. Given that the messages and images used in these ads may persuade parents to purchase these products in accordance with several theoretical perspectives, we argue that overlooking such potential sources of influence is problematic and encourage future research in this area. Such work should examine the attention of parents to food ads and the influence of food ads on parental decision making. Designing and evaluating interventions, including media literacy efforts, may be warranted to help parents be more aware of the ads they are exposed to and how to interpret and utilize information provided ${ }^{(42)}$. Studying nutrition information provided to parents in other forms of media, including websites, is also clearly of interest; as is longitudinal research to see if exposure to nutritional messages, both positive and negative, influence parental attitudes about food and nutrition over time. A better understanding of the role of media in influencing parents' food choices is critical if we are to fully appreciate the role that food marketing plays in promoting and potentially combating the growing obesity problem for both children and adults.

\section{Acknowledgements}

Sources of funding: Work conducted as part of this project was supported by funding from the award CDC K01DP001129: 'Roles of the News Media in Knowledge Dissemination Around Nutritious Diet'. Conflicts of interest: The authors have no conflicts of interest to declare. Ethics: Ethical approval was not sought because the study did not involve human subjects. Authors' contributions: J.A.M. directed the study, collected ad content data and nutrition data, conducted the analysis of ad content data and took the lead on manuscript writing. K.C.S. assisted with methodological decisions, collection of ad content data, interpretation of results and manuscript writing. K.S. assisted with the development of content analysis methods, collection of ad content data, collection of nutrition data and manuscript writing. A.C.S. assisted with the methodology for nutrition data collection and manuscript writing, and led the nutrition data analysis and interpretation of results.

\section{References}

1. Ogden C \& Carroll M (2010) Prevalence of Obesity among Children and Adolescents: United States, Trends 1963-1965 through 2007-2008. Atlanta, GA: Centers for Disease Control and Prevention.

2. US Department of Health and Human Services (not dated) Childhood Obesity. Washington, DC: Assistant Secretary for Planning and Evaluation, DHSS; available at http:// aspe.hhs.gov/health/reports/child_obesity/

3. Carruth B \& Skinner J (2001) Mothers' sources of information about feeding their children ages 2 months to 54 months. J Nutr Educ 33, 143-147.

4. European Food Information Council (1998) Consumer attitudes to food, nutrition and health. Food Today, August issue; available at http://www.eufic.org/article/en/artid/ consumer-attitudes-food-nutrition-health/

5. Jensen H (1993) Sources of information, consumer attitudes on nutrition, and consumption of dairy products. J Consum Aff 27, 357-376.

6. Foss K \& Southwell B (2006) Infant feeding and the media: the relationship between Parents' Magazine content and breastfeeding, 1972-2000. Int Breastfeed J 1, 10.

7. Gamble M \& Cotugna N (1999) A quarter century of TV food advertising targeted at children. Am J Health Behav 23, 261-268.

8. Harrison K \& Marske AL (2005) Nutritional content of foods advertised during the television programs children watch most. Am J Public Health 95, 1568-1574.

9. Kotz K \& Story M (1994) Food advertisements during children's Saturday morning television programming: are they consistent with dietary recommendations? J Am Diet Assoc 94, 1296-1300.

10. Jones SC \& Reid A (2010) Children's magazines: reading resources or food marketing tools? Public Health Nutr 13, 393-399.

11. Cowburn G \& Boxer A (2007) Magazines for children and young people and the links to Internet food marketing: a review of the extent and type of food advertising. Public Health Nutr 10, 1024-1031.

12. Adams J, Simpson E \& White M (2011) Variations in food and drink advertising in UK monthly women's magazines according to season, magazine type and socio-economic profile of readers: a descriptive study of publications over 12 months. BMC Public Health 11, 268.

13. Adams J \& White M (2009) Socio-economic and gender differences in nutritional content of foods advertised in popular UK weekly magazines. Eur J Public Health 19, 144-149.

14. Zwier S (2009) Medicalisation of food advertising: nutrition and health claims in magazine food advertisements 1990-2008. Appetite 53, 109-113.

15. Jones SC, Andrews KL, Tapsell L et al. (2008) The extent and nature of 'health messages' in magazine food advertising in Australia. Asia Pac J Clin Nutr 17, 317-324.

16. Hill J \& Radimer K (1996) Health and nutrition messages in food advertisements: a comparative content analysis of young and mature Australian women's magazines. J Nutr Educ 28, 313-320.

17. Barr S (1989) Nutrition in food advertising: content analysis of a Canadian women's magazine, Canada 1928-1986. J Nutr Educ 21, 64-72.

18. Hickman B, Gates G \& Dowdy R (1993) Nutritional claims in advertising: a study of four women's magazines. $J$ Nutr Educ 25, 227-235.

19. Lohmann J \& Kant A (2000) Comparison of food groups and health claims appearing in food advertisements in 3 popular magazine categories. J Am Diet Assoc 100, 1396-1399.

20. Pratt C \& Pratt C (1995) Comparative content analysis of food and nutrition advertisements in Ebony, Essence, and Ladies' Home Journal. J Nutr Educ 27, 11-17. 
21. Baker WE (1999) When can affective conditioning and mere exposure directly influence brand choice? J Advertising $\mathbf{2 8}$, 31-46.

22. Harris JL, Brownell KD \& Bargh JA (2009) The food marketing defense model: integrating psychological research to protect youth and inform public policy. Soc Issues Policy Rev 3, 211-271.

23. Morris JD, Woo C, Geason JA et al. (2002) The power of affect: predicting intention. J Advertising Res 42, 7-18.

24. Bandura A (2001) Social Cognitive Theory of mass communication. Media Psychol 3, 265-299.

25. Byrd-Bredbenner C \& Grasso D (1999) A comparative analysis of television food advertisements and current dietary recommendations. Am J Health Stud 15, 169-180.

26. Mink M, Evans A, Moore C et al. (2010) Nutritional imbalance endorsed by televised food advertisements. J Am Diet Assoc 110, 904-910.

27. Ulrichsweb ${ }^{\mathrm{TM}}$ (2008) Ulrich's International Periodicals Directory. http://ulrichsweb.serialssolutions.com/login (accessed April 2008).

28. Meredith Corporation (2011) Parents Audience. http:// www.meredith.com/mediakit/parents/print/audience.html (accessed September 2012).

29. Meredith Corporation (2008) Family Circle Readership. http://www.meredith.com/mediakit/familycircle/production/ readership.html (accessed September 2012).

30. Matsa K-EM, Rosenstiel T \& Moore P (2011) Magazines: by the numbers. http://stateofthemedia.org/2011/magazinesessay/data-page-4/ (accessed March 2012).

31. Institute of Medicine (2007) Nutrition Standards for Foods in Schools: Leading the Way Toward Healthier Youth. Washington, DC: National Academies Press.

32. Center for Safety and Applied Nutrition, Food and Drug Administration (2009) Food Labeling Guide. http://www. fda.gov/Food/GuidanceComplianceRegulatoryInformation/ GuidanceDocuments/FoodLabelingNutrition/FoodLabeling Guide/default.htm (accessed December 2011).
33. Jenkin G, Wilson $\mathrm{N}$ \& Hermanson $\mathrm{N}$ (2008) Identifying 'unhealthy' food advertising on television: a case study applying the UK Nutrient Profile model. Public Health Nutr 12, 614-623.

34. Lingas E, Dorfman L \& Bukofzer E (2009) Nutrition content of food and beverage products on web sites popular with children. Am J Public Health 99, Suppl. 3, S587-S592.

35. Stitt C \& Kunkel D (2008) Food advertising during children's television programming on broadcast and cable channels. Health Commun 23, 573-584.

36. Wofford J, Pinson J, Folmar S et al. (1986) Health-related messages in consumer magazine advertising. J Gen Intern Med 10, 488-490.

37. Williams P (2005) Consumer understanding and use of health claims for foods. Nutr Rev 63, 256-264.

38. Parkin KJ (2006) Food is Love: Advertising and Gender Roles in Modern America. Philadelphia, PA: University of Pennsylvania Press.

39. Pescud M \& Pettigrew S (2012) 'I know it's wrong, but...': a qualitative investigation of low-income parents' feelings of guilt about their child-feeding practices. Matern Child Nutr (Epublication ahead ofprint version).

40. Interagency Working Group on Food Marketed to Children (2011) Preliminary Proposed Nutrition Principles to Guide Industry Self-Regulatory Efforts, Request for Comments. http://www.ftc.gov/os/2011/04/110428foodmarketproposed guide.pdf (accessed March 2012).

41. Sharma L, Teret S \& Brownell K (2010) The food industry and self-regulation: standards to promote success and avoid public health failures. Am J Public Health 100, 240-246.

42. Hindin T, Contento I \& Gussow J (2004) A media literacy nutrition education curriculum for Head Start parents about the effects of television advertising on their children's food requests. J Am Diet Assoc 104, 192-198. 